\title{
ANALISIS KINERJA KEUANGAN DALAM PENGELOLAAN APBD PADA DINAS PENGELOLA KEUANGAN, PENDAPATAN DAN ASET (DPKPA) KABUPATEN MINAHASA SELATAN
}

\author{
Novita Mandagi ${ }^{1}$ \\ Jante J. Tinangon ${ }^{2}$ \\ Jessy D.L Warongan ${ }^{3}$ \\ ${ }^{1,2}$ FakultasEkonomi dan Bisnis, Jurusan Akuntansi \\ Universitas Sam Ratulangi, Manado \\ email : $:$ Vithamandagi21@gmail.com \\ 2jantjetinangon447@gmail.com \\ 3jdmarcus@gmail.com
}

\begin{abstract}
The ability of a region to carry out regional autonomy as measured by financial performance area. The size of the financial performance of one of them is financial management is reflected in the Regional Budget (APBD). This study aimed to analyze the financial performance in the management of budget revenues and expenditures at the Department of Financial Management, Revenue and Assets (DPKPA). In this study the methods of analysis used is descriptive analysis. Data analysis was performed by using financial ratio analysis area and the results are described / portrayed on how the analysis of the financial performance in the management of budget revenues and expenditures at the Department of Financial Management, Revenue and Assets of 2011-2014. The results showed that the ratio of independence included in the category of low, the ratio of the degree of decentralization included in the category of low, level of local financial activities included in the category of low, effective ratio shows the financial performance increased, and the level of efficiency is categorized still less efficient. South Minahasa District Government should optimize regional revenue collection and also perform priorities in budgetary spending in the area.
\end{abstract}

Keywords : financial performance, budget revenue and expenditure, financial management

\section{Latar Belakang}

\section{PENDAHULUAN}

Pemerintahan merupakan suatu organisasi yang diberi kekuasaan untuk mengatur kepentingan Bangsa dan Negara. Lembaga Pemerintah dibentuk umumnya untuk menjalankan aktivitas layanan terhadap masyarakat luas dan sebagai organisasi nirlaba yang mempunyai tujuan bukan mencari keuntungan tetapi untuk menyediakan layanan dan kemampuan meningkatkan pelayanan tersebut dimasa yang akan datang.

Dalam rangka desentralisasi dibentuk dan disusun pemerintah provinsi dan pemerintah kota yang diberikan kewenangan untuk mengatur dan mengurus rumah tangganya sebagai perwujudan otonomi daerah. Disamping itu, adanya tuntutan terhadap penciptaan kondisi perimbangan keuangan antara pemerintah pusat dan daerah yang rasional dan proporsional juga menjadi dasar pentingnya penyelenggaraan otonomi daerah dan desentralisasi fiskal.Tujuan dari pelaksanaan otonomi daerah dan desentralisasi fiscal adalah untuk meningkatkan kemandirian dan mengurangi ketergantungan fiskal pemerintah daerah terhadap pemerintah pusat.

Rahardjo (2011:3), otonomi yang diberikan kepada daerah kabupaten dan kota dilaksanakan dengan memberikan kewenangan yang luas, nyata dan bertanggung jawab kepada pemerintah daerah 
secara proporsional dan pemanfaatan sumberdaya nasional yang berkeadilan, serta perimbangan keuangan pusat dan daerah. Otonomi Daerah merupakan pemberdayaan dalam pengambilan keputusan secara lebih leluasa untuk mengelola sumber daya yang dimiliki sesuai dengan kepentingan, prioritas, dan potensi daerah sendiri. Dengan adanya otonomi daerah kabupaten, kota dan provinsi, maka pengelolaan keuangan sepenuhnya berada di tangan pemerintah daerah itu sendiri.

Untuk mengetahui kesiapan suatu daerah dalam menghadapi otonomi daerah, maka perlu dilakukan suatu analisis terhadap kinerja pemerintah daerah dalam mengelola keuangan daerahnya demi mewujudkan tingkat kemandirian dalam era otonomi daerah.Menilai kinerja keuangan pemerintah daerah dapat dilakukan dengan cara melihat kinerjanya melalui Laporan Realisasi Anggaran. Laporan Realisasi Anggaran menggambarkan perbandingan antara anggaran dengan realisasinya dalam suatu periode pelaporan. Laporan Realisasi Anggaran juga menyediakan informasi yang beguna dalam memprediksi sumber daya ekonomi yang akan diterima untuk mendanai kegiatan pemerintah daerah dalam periode mendatang dengan cara menyajikan laporan secara komparatif.

Sistem Akuntansi Pemerintah Daerah merupakan rangkaian sistematik dari prosedur penyelenggara, peralatan dan elemen lain untuk mewujudkan fungsi akuntansi sejak analisis transaksi sampai dengan pelaporan keuangan dilingkungan organisasi Pemerintah Daerah. Penyusunan Anggaran Pendapatan Belanja Daerah (APBD) merupakan gambaran tentang penerimaan dan pengeluaran daerah selama satu tahun anggaran sehingga pada akhir tahun anggaran pemerintah daerah diwajibkan menyusun laporan keuangan sebagai bentuk pertanggungjawaban pengelolaan keuangan daerah selama satu tahun periode.Analisis rasio keuangan merupakan salah satu alat untuk menganalisis laporan keuangan dan dari analisis rasio keuangan yang dilakukan pada laporan keuangan Pemerintah Daerah Kabupaten Minahasa Selatan tersebut dapat dijadikan sebagai penilaian kinerja keuangan pada Pemerintah Daerah.

\section{Tujuan Penelitian}

Tujuan penelitian ini adalah untuk mengetahui kinerja keuangan dalam Pengelolaan Anggaran Pendapatan dan Belanja Daerah pada Dinas Pengelola Keuangan, Pendapatan dan Aset (DPKPA) Kabupaten Minahasa Selatan.

\section{TINJAUAN PUSTAKA}

Akuntansi adalah sistem informasi yang mengidentifikasi, mencatat dan mengkomunikasikan peristiwa ekonomi dari suatu organisasi kepada pihak yang memiliki kepentingan. Weygandt, Kimmel \& Kieso (2011:7).

Akuntansi Pemerintah adalah bidang akuntansi yang berkaitan dengan lembaga pemerintahan dan lembaga yang tidak betujuan mencari laba. Fungsi akuntansi pemerintahan lebih ditekankan pada pencatatan pelaksanaan anggaran negara serta pelaporan realisasinya.

\section{Standar Akuntansi Pemerintahan}

Akuntansi pemerintahan sendiri memiliki standar tersendiri yaitu Standar Akuntansi Pemerintahan. Menurut Permendagri No. 64 tahun 2013 pasal 1 ayat 3 menyatakan standar akuntansi pemerintahan yang selanjutnya disingkat SAP adalah prinsip-prinsip akuntansi yang diterapkan dalam menyusun dan menyajikan laporan keuangan pemerintah. 


\section{Kedudukan Standar Akuntansi Pemerintahan}

Standar akuntansi pemerintahan ditetapkan dengan peraturan pemerintah yaitu Peraturan Pemerintah Nomor 71 Tahun 2010 tentang Standar Akuntansi Pemerintahan. Adapun kedudukan SAP yang dinyatakan oleh Bastian (2010:139) sebagai berikut:

1. Sesuai dengan UU No. 17 Tahun 2003 tentang Keuangan Negara, Standar Akuntansi Pemerintahan ditetapkan dengan Peraturan Pemerintah.

2. Setiap entitas pelaporan pemerintah pusat dan pemerintah daerah wajib menerapkan Standar Akuntansi Pemerintahan. Pada penerapannya, muncul kebutuhan akan upaya pengharmonisasian berbagai peraturan baik di Pemerintah pusat maupun di Pemerintah daerah dengan SAP.

\section{Indikator Standar Akuntansi Pemerintahan}

Menurut Bastian (2010:140) dan Peraturan Pemerintah Nomor 71 Tahun 2010 tentang Standar Akuntasi Pemerintahan, penyajian laporan keuangan terdiri sebagai berikut:

1. Basis akrual

2. Komponen laporan keuangan

3. Periode pelaporan

\section{Sistem Akuntansi Pemerintah Daerah}

Sistem akuntansi pemerintah daerah adalah serangkaian prosedur mulai dari proses pengumpulan data, pencatatan, pengikhtisaran, sampai dengan pelaporan keuangan, dalam rangka pertanggungjawaban pelaksanaan APBD yang dapat dilakukan secara manual atau menggunakan aplikasi komputer (Nordiawan 2010:201)

\section{Sistem Pengendalian Internal Pemerintah}

Menurut Peraturan Pemerintah Nomor 60 Tahun 2008 tentang Sistem Pengendalian Intern Pemerintah menyatakan bahwa: Sistem Pengendalian Internal adalah proses yang integral pada tindakan dan kegiatan yang dilakukan secara terus menerus oleh pimpinan dan seluruh pegawai untuk memberikan keyakinan memadai atas tercapainya tujuan organisasi melalui kegiatan yang efektif dan efisien, keandalan pelaporan keuangan, pengamanan asset Negara, dan ketaatan terhadap peraturan perundangundangan.

Unsur-unsur sistem pengendalian internal menurut Peraturan Pemerintah No.60 tahun 2008 adalah :

1. Lingkungan pengendalian

2. Penilaian risiko

3. Kegiatan pengendalian

4. Informasi dan komunikasi

5. Pemantauan pengendalian intern

\section{Laporan Keuangan Pemerintah Daerah}

Laporan keuangan terutama digunakan untuk membandingkan realisasi pendapatan, belanja, transfer dan pembiayaan dengan anggaran yang telah ditetapkan, menilai kondisi keuangan, mengevaluasi efektivitas dan efisiensi suatu entitas pelaporan dan membantu menentukan ketaatannya terhadap 
perundang-undangan (Fidelius 2013). PP No. 71 Tahun 2010 menjelaskan laporan keuangan pemerintah terdiri dari :

1. Laporan Realisasi Anggaran

2. Laporan Perubahan Saldo Anggaran Lebih

3. Laporan Operasional

4. Neraca

5. Laporan Arus Kas

6. Laporan Perubahan Ekuitas

7. Catatan Atas Laporan Keuangan.

\section{Kinerja Keuangan}

Kinerja Keuangan merupakan gambaran dari pencapaian keberhasilan perusahaan dapat diartikan sebagai hasil yang telah dicapai atas berbagai aktivitas yang telah dilakukan. Dapat dijelaskan bahwa kinerja keuangan adalah suatu analisis yang dilakukan untuk melihat sejauh mana suatu perusahaan telah melaksanakan dengan menggunakan aturan-aturan pelaksanaan keuangan secara baik dan benar (Fahmi,2012:2). Selanjutnya dalam kaitannya dengan pemerintah daerah, Kinerja Keuangan Pemerintah Daerah adalah keluaran atau hasil dari kegiatan atau program yang akan atau telah dicapai sehubungan dengan penggunaan anggaran daerah dengan kualitas dan kuantitas yang terukur, kemampuan daerah dapat diukur dengan menilai efisiensi atas pelayanan yang diberikan kepada masyarakat (Sumarjo,2010).

\section{Pengelolaan Keuangan Daerah}

Dalam ketentuan umum pada PP Nomor 58 Tahun 2005, Pengelolaan Keuangan Daerah adalah keseluruhan kegiatan yang meliputi perencanaan, pelaksanaan, penatausahaan, pelaporan dan pertanggungjawaban, pengawasan daerah. Pengelolaan keuangan daerah dalam hal ini mengandung beberapa kepengurusan dimana kepengurusan umum atau yang sering disebut pengurusan administrasi dan kepengurusan khusus atau juga sering disebut pengurusan bendaharwan. Dalam pengelolaan anggaran/keuangan daerah harus mengikuti prinsip-prinsip pokok anggaran sektor publik.

\section{Anggaran Pendapatan dan Belanja Daerah (APBD)}

Anggaran Pendapatan dan Belanja Daerah adalah suatu rencana keuangan tahunan daerah yang ditetapkan berdasarkan peraturan daerah tentang Anggaran Pendapatan dan Belanja Daerah yang disetujui oleh Dewan Perwakilan Rakyat Daerah (UU No. 23 Tahun 2014). Anggaran Pendapatan dan Belanja Daerah atau juga dikenal dengan Anggaran Daerah adalah suatu bentuk kongkrit rencana kerja keuangan daerah yang komprenhensif yang mengakibatkan penerimaan dan pengeluaran pemerintah daerah yang dinyatakan dalam bentuk uang untuk mencapai tujuan atau target yang direncanakan dalam jangka waktu tertentu dalam satu tahun anggaran. Rahardjo (2011:50).

Anggaran Pendapatan dan Belanja Daerah (APBD) menurut Rahayu (2010: 293) merupakan wujud pengelolaan keuangan daerah yang setiap tahunnya ditetapkan dengan Peraturan Daerah. Anggaran Pendapatan dan Belanja Daerah terdiri atas:

1. Anggaran Pendapatan Daerah

2. Anggaran belanja daerah

3. Pembiayaan Daerah

\section{Konsep Analisis Rasio Keuangan}

Menurut Mahmudi $(2010,88)$ analisis rasio keuangan merupakan perbandingan antara dua angka yang datanya dari elemen laporan keuangan.Analisis rasio keuangan dapat digunakan untuk 
mengintepretasikan perkembangan kinerja dari tahun ke tahun dan membandingkannya dengan kinerja organisasi lain yang sejenis. Analisis rasio keuangan pada APBD dilakukan dengan cara membandingkan hasil yang dicapai oleh suatu daerah dari satu periode terhadap periode sebelumnya, sehingga dapat diketahui bagaimana kecenderungan yang terjadi. Sedangkan menurut Harahap (2010:297) Analisis Rasio Keuangan adalah angka yang diperoleh dari hasil perbandingan dari satu pos laporan keuangan dengan pos lainnya yang mempunyai hubungan yang relevan dan signifikan. Dalam penelitian ini, pengukuran kinerja keuangan daerah dilakukan dengan menggunakan rasio-rasio sebagai berikut:

\section{Konsep Kemandirian Keuangan Daerah}

Rasio Kemandirian menggambarkan ketergantungan daerah terhadap sumber dana ekstern. Rasio kemandirian juga menggambarkan tingkat partisipasi masyarakat dalam pembangunan daerah. Semakin tinggi rasio kemandirian, semakin tinggi partisipasi masyarakat dalam membayar pajak dan retribusi daerah yang merupakan komponen utama pendapatan asli daerah. Semakin tinggi masyarakat membayar pajak dan retribusi daerah akan menggambarkan tingkat kesejahteraan masyarakat yang semakin tinggi (Mahmudi, 2010: 140). Dengan rumus sebagai berikut:

Rasio Kemandirian $=\frac{\text { Pendapatan Asli Daerah }}{\text { Bantuan Pemerintah Pusat/Propinsi dan Pinjaman }}$ 100\%

\section{Konsep Derajat Desentralisasi}

Derajat desentralisasi dihitung berdasarkan perbandingan antara jumlah Pendapatan Asli Daerah (PAD) dengan total penerimaan daerah. Rasio ini menunjukkan derajat kontribusi PAD terhadap total penerimaan daerah. Semakin tinggi kontribusi PAD, maka semakin tinggi kemampuan pemerintah daerah dalam penyelenggaraan desentralisasi (Mahmudi, 2010:169). Rasio Derajat Desentralisasi menunjukkan kewenangan dan tanggung jawab yang diberikan pemerintah pusat kepada pemerintah daerah untuk menggali dan mengelola pendapatan. Rasio Derajat Desentralisasi dapat dirumuskan sebagai berikut:

Derajat Desentralisasi $=\ldots$ Pendapatan Asli Daerah $\times 100 \%$

Total Pendapatan Daerah

\section{Konsep Aktivitas Keuangan Daerah}

Rasio ini menggambarkan bagaimana pemerintah daerah memprioritaskan alokasi dananya pada belanja rutin/belanja operasi dan belanja pembangunan/ belanja modal secara optimal. Semakin tinggi presentase dana yang dialokasikan untuk belanja rutin berarti persentase belanja investasi (belanja pembangunan) yang digunakan untuk menyediakan sarana prasarana ekonomi masyarakat cenderung semakin kecil. rasio belanja pembangunan yang relatif masih kecil perlu ditingkatkan sesuai dengan kebutuhan pembangunan di daerah (Halim dalam Lutfia 2011). Dengan rumus sebagai berikut:

Belanja Pembangunan terhadap APBD $=\frac{\text { Total Belanja Pembangunan }}{\text { Total APBD }} \times 100 \%$

\section{Konsep EfektivitasKeuangan Daerah}

Rasio efektivitas menggambarkan kemampuan pemerintah daerah dalam merealisasikan pendapatan asli daerah yang direncanakan dibandingkan dengan target yang ditetapkan berdasarkan potensi riil daerah. Kemampuan daerah dikategorikan efektif apabila rasio yang dicapai mencapai minimal sebesar 1 (satu) atau 100 persen. Namun demikian semakin tinggi rasio efektifitas, menggambarkan kemampuan daerah yang semakin baik. Guna memperoleh ukuran yang lebih baik, rasio 
efektifitas tersebut perlu dipersandingkan dengan rasio efisiensi yang dicapai pemerintah daerah. (Mahmudi, 2010: 143). Dengan rumus sebagai berikut:

Rasio Efektifitas $=\frac{\text { Realisasi Penerimaan }}{\text { Target Penerimaan }} \times 100 \%$

\section{Konsep Efisiensi Keuangan Daerah}

Efisiensi berhubungan erat dengan konsep produktivitas. Pengukuran efisiensi dilakukan dengan menggunakan perbandingan antara output yang dihasilkan terhadap input yang digunakan(cost of output). Proses kegiatan operasional dapat dikatakan efisien apabila suatu produk atau hasil kerja tertentu dapat dicapai dengan penggunaan sumber daya dan dana yang serendah-serendahnya (spending well). (Mardiasmo,2009:132). Sedangkan menurut (Raharjo 2011:169)dalam buku Pengelolaan dan Pendapatan Anggaran Daerah mengemukakan bahwa efisiensi merupakan suatu kondisi atau keadaan, dimana penyelesaian suatu pekerjaan dilaksanakan dengan benar dan dengan penuh kemampuan yang dimiliki.Dengan rumus sebagai berikut:

Rasio Efisiensi $=\frac{\text { Pengeluaran }}{\text { Realisasi Penerimaan }} \times 100 \%$

\section{Penelitian Terdahulu}

Saputra (2016) dalam penelitian ini berjudul Analisis Kinerja Keuangan Pemerintah Daerah Dalam Pengelolaan Anggaran Pendapatan Dan Belanja Daerah Di Kabupaten Jembrana. Tujuan dalam penelitian ini untuk mengetahui sejauh mana tingkat kinerja keuangan dalam pengelolaan APBD Di Kabupaten Jembrana. Metode yang digunakan adalah deskriptif. Hasil dari penelitian ini menunjukan bahwa tingkat dilihat dari rasio derajat desentralisasi termasuk dalam kategori sangat kurang, dilihat dari rasio kemandirian keuangan daerah termasuk dalam kategori rendah sekali.Yuliana(2013) dalam penelitian yang berjudul Analisis Kinerja Anggaran Pendapatan Dan Belanja (APBD)Ditinjau Dari Rasio Keuangan Pemerintah Daerah Kabupaten Sragen. Bertujuan untukmengetahui kinerja pada APBD dengan menggunakan Rasio Keuangan. Metode yang digunakan adalah Deskriptif.Hasil penelitian menunjukkan rasio keuangan pada APBD PemerintahDaerah Kabupaten Sragen tahun 2010-2012 dapat disimpulkan bahwa kinerjasudah baik.

\section{Jenis Penelitian}

\section{METODE PENELITIAN}

Adapun jenis Penelitian ini adalah penelitian deskriptif. Penelitian deskriptif yaitu, penelitian yang dilakukan untuk mengetahui nilai variabel mandiri, baik satu variabel atau lebih (independen) atau menghubungkan dengan variabel yang lain. Sugiyono (2012: 13).

\section{Tempat dan Waktu Penelitian}

Tempat penelitian dilakukan pada Dinas Pengelola Keuangan, Pendapatan dan Aset (DPKPA) Kabupaten Minahasa Selatan dengan alamat Jln. Trans Sulawesi, Kelurahan Pondang, Lingkungan XII. Waktu pelaksanaan penelitian dilakukan pada bulan Februari sampai Mei 2016.

\section{Prosedur penelitian}

Prosedur/langkah-langkah penelitian yang dilakukan adalah sebagai berikut :

1. Mengumpulkan gambaran umum dan permasalahan yang ada mengenai Kinerja Keuangan Dalam Pengelolaan Anggaran Pendapatan Dan Belanja (APBD) Pada Dinas Pengelola Keuangan, Pendapatan Dan Aset (DPKPA) Kabupaten Minahasa Selatan 
2. Mengumpulkan data AnggaranPendapatan dan Belanja Dinas Pengelolaan Keuangan, Pendapatan dan Aset Kabupaten Minahasa Selatan.

3. Menilai kemandirian keuangan daerah dalam membiayai penyelenggaraanotonomi daerah.

4. Mengukur sejauh mana aktivitas Pemerintah Daerah dalammembelanjakan pendapatan daerahnya.

5. Mengukur efektifitas dan efisiensi dalam merealisasikan pendapatandaerah.

6. Memberikan kesimpulan dan saran sehingga dapat menjadi masukan bagi Dinas Pengelolaan Keuangan, Pendapatan dan Aset (DPKPA) Kabupaten Minahasa Selatan

\section{Jenis Data}

Kuantitatif, yaitu data yang berbentuk angka (bilangan). Sesuai kriterianya, data kuantitatif bisa diolah atau dianalisis memakai teknik perhitungan statistika (matematika).

\section{Sumber Data}

Sumber data yang digunakan dalam penelitian ini adalah sumber data primer yaitu melakukan penelitian langsung pada Dinas Pengelola Keuangan, Pendapatan dan Aset (DPKPA) dan sumber data sekunder untuk memperoleh dokumentasi.

\section{Teknik Pengumpulan Data}

Teknik pengumpulan data yang digunakan dalam penelitian ini adalah wawancara dilakukan dengan tanya jawab serta diskusi langsung dengan pihak Dinas Pengelola Keuangan, Pendapatan dan Aset (DPKPA) Kabupaten Minahasa Selatan. Selanjutnya observsi yaitu dengan melakukan pengamatan dan pengumpulan data secara langsung pada (DPKPA) Kabupaten Minahasa Selatan. Dan dokumentasi yaitu dengan cara mempelajari dokumen, bukti-bukti atau catatan yang berhubungan dengan data yang diperlukan.

\section{Metode Analisis}

Metode analisis yang digunakan untuk menganalisa hasil penelitian ini adalah dengan analsis deskriptif kuantitatif, dengan rasio keuangan pada Dinas Pengelola Keuangan, Pendapatan dan Aset (DPKPA) Kabupaten Minahasa Selatan tahun 2011 sampai dengan tahun 2014

\section{HASIL PENELITIAN DAN PEMBAHASAN}

\section{Hasil Penelitian}

Penelitian ini akan membahas bagaimana kinerja keuangan dalam pengelolaan APBD pada Dinas Pengelola Keuangan, Pendapatan dan Aset (DPKPA) Kabupaten Minahasa Selatan tahun anggaran 2011 sampai 2014.

\section{Rasio Kemandirian}

Dari perhitungan Kemandirian Keuangan Daerah dengan menggunakan rasio perbandingan antara Bantuan Pemerintah Pusat/Propinsi dan Pinjaman dengan pendapatan asli daerah Dinas Pengelola Keuangan, Pendapatan dan Aset (DPKPA) Kabupaten Minahasa Selatan. 
Tabel 1. Kemandirian

\begin{tabular}{clll}
\hline $\begin{array}{c}\text { Tahun } \\
(\text { Rp) }\end{array}$ & $\begin{array}{c}\text { PAD } \\
\text { dan Pinjaman }(\mathbf{R p})\end{array}$ & & Bantuan Pemerintah Pusat/PropinsiPersentase \\
\hline 2011 & $9.407 .280 .004,00$ & $506.484 .072 .253,00$ & $1,85 \%$ \\
2012 & $10.620 .087 .945,00$ & $526.709 .559 .627,00$ & $2,30 \%$ \\
2013 & $14.406 .092 .809,00$ & $518.402 .298 .599,00$ & $2,70 \%$ \\
2014 & $26.137 .234 .620,00$ & $654.665 .686 .881,00$ & $3,90 \%$ \\
\hline
\end{tabular}

Sumber : Data Olahan 2016

Berdasarkan perhitungan diatas, dapat dilihat bahwa tingkat Kemandirian keuangan daerah (DPKPA) Kabupaten Minahasa Selatan pada tahun 2011 berada pada tingkat 1,85\%, tahun 2012 berada pada tingkat 2,30\%, tahun 2013 berada pada tingkat 2,70\%, dan pada tahun 2014 berada pada tingkat 3,90\%,Dengan demikian dapat diberikan penilaian dengan menggunakan kriteria kinerja keuangan maka tingkat kemandirian keuangan daerah DPKPA Kabupaten Minahasa Selatan berada pada tingkat 0-25\% berada pada kategori Rendah Sekali.

\section{Rasio Derajat Desentralisasi}

Dari perhitungan Derajat Desentralisasi Pengelolaan Keuangan Daerah dengan menggunakan rasio perbandingan antara Pendapatan Asli Daerah dengan Total Pendapatan Daerah DPKPA Kabupaten Minahasa Selatan.

Tabel 2. Derajat Desentralisasi

\begin{tabular}{llcl}
\hline Tahun & \multicolumn{2}{c}{ PAD (Rp)Total Pendapatan Daerah (Rp) } & Persentase \\
\hline 2011 & $9.407 .280 .004,00$ & $515.891 .352 .257,00$ & $1,82 \%$ \\
2012 & $10.620 .087 .945,00$ & $537.329 .647 .572,00$ & $1,90 \%$ \\
2013 & $14.406 .092 .809,00$ & $604.614 .969 .408,00$ & $2,38 \%$ \\
2014 & $26.137 .234 .620,00$ & $684.371 .721 .501,00$ & $3,81 \%$ \\
\hline
\end{tabular}

Sumber : Data Olahan 2016

Berdasarkan perhitungan diatas, maka tingkat Derajat Desentralisasi keuangan daerah (DPKPA) Kabupaten Minahasa Selatan pada tahun 2011 berada pada tingkat 1,82\%, tahun 2012 berada pada tingkat 1,90\%, tahun 2013 berada pada tingkat 2,38\% , dan pada tahun 2014 berada pada tingkat 3,81\%,Dengan demikian dapat diberikan penilaian dengan menggunakan kriteria kinerja keuangan maka tingkat Desentralisasi keuangan daerah DPKPA Kabupaten Minahasa Selatan berada pada tingkat 0-25\% berada pada kategori Rendah Sekali.

\section{Rasio Aktivitas}

Dari perhitungan Aktivitas Keuangan Daerah dengan menggunakan rasio perbandingan antara Total Belanja Pembangunan dengan Total Pendapatan Daerah (DPKPA) Kabupaten Minahasa Selatan.

Tabel 3. Aktivitas

\begin{tabular}{llll}
\multicolumn{4}{l}{ TahunTotal Belanja PembangunanTotal Pendapatan DaerahPersentase } \\
\hline 2011 & $84.390 .024 .651,00$ & $515.891 .352 .257,00$ & $16,35 \%$ \\
2012 & $107.544 .472 .940,00$ & $537.329 .647 .572,00$ & $20,01 \%$ \\
2013 & $102.467 .563 .469,00$ & $604.614 .969 .408,00$ & $16,94 \%$ \\
2014 & $132.953 .173 .803,00$ & $684.371 .721 .501,00$ & $19,42 \%$ \\
\hline
\end{tabular}

Sumber : Data Olahan 2016

Dari hasil perhitungan diatas, maka Aktivitas keuangan daerah DPKPA Kabupaten Minahasa Selatan pada tahun 2011 berada pada tingkat 16,35\%, tahun 2012 berada pada tingkat 20,01\%, tahun 2013 berada pada tingkat 16,94\% , dan pada tahun 2014 berada pada tingkat $19,42 \%$. Berada pada kategori tingkat 0-25\% keatas. Hal ini menunjukkan bahwa tingkat Aktivitas keuangan daerah DPKPA Kabupaten Minahasa Selatan Rendah Sekali. 


\section{Efektivitas}

Perhitungan Efektivitas menggambarkan kemampuan pemerintah daerah dalam merealisasikan Pendapatan Asli Daerah yang direncanakan dibandingkan dengan target yang dietapkan berdasarkan potensi riil daerah. Semakin tinggi Rasio Efektivitas, menggambarkan kemapmpuan daerah yang semakin baik.

Tabel 4. Tingkat Efektivitas Keuangan

\begin{tabular}{cccr}
\hline Tahun & Realisasi PenerimaanTarget & PenerimaanRasio Efisiensi \\
\hline 2011 & Rp.515.891.352.257,00 & Rp. $.519 .322 .927 .489,00$ & $99,33 \%$ \\
2012 & Rp.537.329.647.572,00 & Rp.535.044.213.864,00 & $100,42 \%$ \\
2013 & Rp.604.614.969.408,00 & Rp.601.087.914.509,00 & $100,58 \%$ \\
2014 & Rp.684.371.721.501,00 & Rp.690.625.976.980,00 & $99,94 \%$ \\
\hline
\end{tabular}

Sumber : Data Olahan 2016

Untuk mengetahui Rasio Efektivitas. Pada kolom pertama mencantumkan tahun anggaran yaitu tahun 2011 sampai 2014 dan pada kolom kedua dan ketiga adalah Target dan Realisasi yang merupakan Target Penerimaan PAD dan Realisasi Penerimaan PAD. Secara keseluruhan, rata-rata tingkat efektivitaskeuangan daerah pada DPKPA Kabupaten Minahasa Selatan tahun anggaran 2011 sampai 2014 pada persentase $100,42 \%$ dan dinyatakan sangat efektif. Hal ini menunjukan kinerja pemerintah dalam merealisasikan pendapatan asli daerah berdasarkan potensi riil daerah dalam tahun anggran 2011-2014 sudah sangat baik.

\section{Efisiensi}

Efisiensi merupakan suatu pengukuran perbandingan antara realisasi pengeluaran rutin dan realisasi pendapatan dalam melaksanakan suatu pekerjaan. Semakin kecil rasio efisien, maka semakin baik, begitu pulasebaliknya.

Tabel 5. Tingkat Efisiensi Keuangan Daerah

\begin{tabular}{ccccc}
\hline Tahun & \multicolumn{2}{c}{ Pengeluaran Rutin (Belanja) } & Penerimaan & Rasio Efisiensi \\
\hline 2011 & Rp.483.807.278.567,00 & Rp.515.891.352.257,00 & $93,79 \%$ \\
2012 & Rp.525.891.166.484,00 & Rp.537.329.647.572,00 & $97,88 \%$ \\
2013 & Rp.561.242.693.084,00 & Rp.604.614.969.408,00 & $92,83 \%$ \\
2014 & Rp.689.167.009.246,00 & Rp.684.371.721.501,00 & $100,01 \%$ & \\
\hline
\end{tabular}

Sumber : Data Olahan 2016

Tingkat efisiensi pengelolaan keuangan daerah DPKPA Kabupaten Minahasa Selatan pada tahun 2011 berada pada tingkat 93,79\%, tahun 2012 berada pada tingkat 97,88\%, tahun 2013 berada pada tingkat 92,83\% , dan pada tahun 2014 berada pada tingkat 100,01\%. Dengan demikian dapat diberikan penilaian dengan menggunakan kriteria kinerja keuangan maka tingkat efisiensi pengelolaan keuangan daerah DPKPA Kabupaten Minahasa Selatan berada pada tingkat 90\% keatas. Hal ini menunjukkan bahwa tingkat efisiensi pengelolaan keuangan daerah DPKPA Kabupaten Minahasa Selatan Kurang Efisien.

\section{Kesimpulan}

\section{PENUTUP}

Kesimpulan dalam penelitian ini adalah sebagai berikut.

1. Berdasarkan analisis rasio keuangan yakni rasio kemandirian menyatakan bahwa selama 4 tahun tersebut kinerja keuangan daerah DPKPA Kabupaten Minahasa Selatan belum mencapai kemandirian karena bagian dana dari pihak eksternal masih mendominasi perolehan pendapatan daerah dan dilihat dari trend presentase kemandirian keuangan DPKPA Kabupaten Minahasa Selatan kinerja keuangan daerah dikategorikan rendah sekali. Hal ini menggambarkan ketergantungan daerah terhadap pusat sangat tinggi. 
2. Kinerja pendapatan dilihat dari analisis rasio keuangan yaitu dari derajat desentralisasi DPKPA Kabupaten Minahasa Selatan masih rendah dan masih cenderung menurun.

3. Untuk rasio aktivitas kinerja keuangan dari Pemerintah Kabupaten Minahasa Selatan selama 4 tahun tersebut dalam hal pengeluaran untuk belanja modal/ belanja pembangunan dikategorikan rendah sekali

4. Tingkat efektivitas pengelolaan keuangan DPKPA Kabupaten Minahasa Selatan dari tahun 20112014 rata-rata diatas 100\%. Hal ini berarti bahwa pengelolaan keuangan daerah Dinas Pengelola Keuangan, Pendapatan dan Aset Kabupaten Minahasa Selatan sangat efektif.

5. Tingkat efisiensi pengelolaan keuangan daerah DPKPA Kabupaten Minahasa Selatan dengan menggunakan rumus, yaitu rasio perbandingan dan diberikan penilaian dengan menggunakan kriteria penilaian, maka tingkat efisiensi pengelolaan keuangan daerah Dinas Pengelola Keuangan, Pendapatan dan Aset Kabupaten Minahasa Selatan dari tahun 2011-2014 kurang efisien. Hal ini dikarenakan pengeluaran daerah masih tinggi dibandingkan total penerimaan daerah.

\section{Saran}

Saran yang dapat diberikan adalah:

1. Agar Pemerintah Kabupaten Minahasa Selatan dapat meningkatkan dan mengoptimalkan perolehan sumber-sumber PAD serta peningkatan SDM aparat yang terkait dengan perolehan PAD dan juga Pemerintah Kabupaten Minahasa Selatan harus dapat bertindak sekaligus bersikap efesien dan efektif.

2. Dalam rangka menghadapi otonomi daerah khususnya mempersiapkan sumber daya manusia, baiknya Kabupaten Minahasa Selatan dapat lebih mengatur penerimaan daerah agar bisa menyesuaikan dengan pengeluaran rutin sehingga pengelolaan keuangan daerah Dinas Pengelola Keuangan, Pendapatan dan Aset Kabupaten Minahasa Selatan bisa diatur dan efisien.

3. Disarankan kepada pembaca lain atau peneliti lain untuk dapat mengembangkan penelitian yang berhubungan dengan pengelolaan keuangan daerah.

\section{DAFTAR PUSTAKA}

Bastian, Indra. 2010. Akuntansi Sektor Publik Suatu Pengantar. Edisi Ketiga. Penerbit Erlangga. Jakarta Fahmi, Irham. 2012. Analisis Laporan Keuangan. Cetakan kedua. Bandung. Alfabeta

Hendro, Sumarjo. 2010. Pengaruh Karakteristik Pemerintah Daerah Terhadap Kinerja Keuangan Pemerintah Daerah. Skripsi. Universitas Sebelas Maret Surakarta.

Harahap, Sofian Safri. 2010. Analisis Kritis Atas Laporan Keuangan. Jakarta. Rajawali Persada

Halim, Abdul (2012). Akuntansi Sektor Publik Akuntansi Keuangan Daerah. $\quad$ Edisi $\quad$ ke 4. Penerbit Salemba Empat. Jakarta

Mahmudi,2010.Manajemen Keuangan Daerah,Jakarta, Penerbit Erlangga.

Mardiasmo. 2009. Akuntansi Sektor Publik. Andi. Yogyakarta.

Nordiawan,dkk. 2010. Akuntansi Sektor Publik . Edisi 2.Jakarta. Selemba Empat

Pemerintah Republik Indonesia. Permendagri No. 64 tahun 2013 pasal 1 ayat 3 tentang Standar Akuntansi Pemerintahan. Jakarta.

Peraturan Pemerintah (PP) Republik Indonesia Nomor 60 Tahun 2008 tentang SistemPengendalian Intern Pemerintah.

Peraturan Pemerintah (PP). Republik Indonesia. Nomor 58 Tahun 2005, Pengelolaan Keuangan Daerah. Jakarta

Pemerintah Republik Indonesia. Undang-Undang Nomor 23 Tahun 2014 tentang Pemerintahan Daerah. Jakarta.

RahardjoAdisasmita, 2011. Pengelolaan Pendapatan Dan Anggaran Daerah. Cetakan Pertama, Yogyakarta, Penerbit Graha Ilmu

Rahayu, Ani Sri 2010. Pengantar Kebijakan Fiskal. Jakarta. Bumi Aksara 
Saputra .2016. Analisis Kinerja Keuangan Pemerintah Daerah Dalam Pengelolaan Anggaran Pendapatan Dan Belanja Daerah Di Kabupaten Jembranatahun 2010 - 2014. Skripsi. e-Journal Bisma Universitas Pendidikan Ganesha Jurusan Manajemen (Volume 4 Tahun 2016)

Sugiyono. 2012. Metode Penelitian Kuantitatif Kualitatif dan $R \& D$,Bandung.Alfabeta Weygandt, Kimmel \& Kieso 2011. Financial accounting FIRS Edition. Hoboken: John Wiley \& Son Yuliana. 2013. Analisis Kinerja Anggaran Pendapatan Dan Belanja (APBD) Ditinjau Dari Rasio Keuangan Di Kabupaten Sragen. Jurnal Akuntansi.Universitas Surakarta. Muhammadiyah 